\title{
外科系における $\mathrm{B}$ 型肝炎予防対策
}

\section{1. はじめに}

$\mathrm{B}$ 型肝炎 $(\mathrm{HB})$ は，院内感染症として大きな 話題を呼んだ疾患であり，手術時の輸血を介し ての感染や，医療從事者の感染が高率に発生し たが，今日，HBの感染防止対策はほぼ確立さ れたものと考える.

特に1981年 5 月 11 日, 液状抗 HBs 人免疫グ ロブリンの発売が認可され，9月1日，薬価基 準に収載されるに至り，HB の感染防止対策は さらに大きな進歩を遂げ，すでに開発されてい るワクチンが実用化すれば，完全に解決される ことになろう。

しかし予防対策の方法論は結論をみたものの, 現実においては検查体制, 予防体制, それらに 伴う予算等に施設による差異が大きく, 理想の 予防対策を実現するには多少の月日を必するも のと考える.このよらな見地から，現段階で行 、得る理想的予防対策に言及し，すべての施設 が 1 日も早く $\mathrm{HB}$ 予防対策を確立する一助とし たい。

\section{HBウイルス関連抗原, 抗体}

B 型肝炎を起こす微生物はB型肝炎ウイルス (Dane 粒子ともいわれる) であり，その直経 は42nm（約ナノメーター， $1 \mathrm{~nm}=1 / 1,000,000$ $\mathrm{mm}$ ) で, 直経約 $27 \mathrm{~nm}$ の芯 core とそれを覆 う厚さ約 $7.5 \mathrm{~nm}$ の外被 outer coat よりなる 粒子である。

このウイルスに関連した抗原，抗体には，現 在, 下記の 6 種類があり，抗原は図 1 に示すと おりである。

* 東京大学医学部附属病院中央手術部
小林寛 伊*
$\mathrm{HBs}$ 抗原 $\mathrm{HBs} A g$
HBs 抗体 anti-HBs
HBe 抗原 $\mathrm{HBeAg}$
$\mathrm{HBe}$ 抗体 anti-HBe
$\mathrm{HBc}$ 抗原 $\mathrm{HBcAg}$
$\mathrm{HBc}$ 抗体 anti-HBc

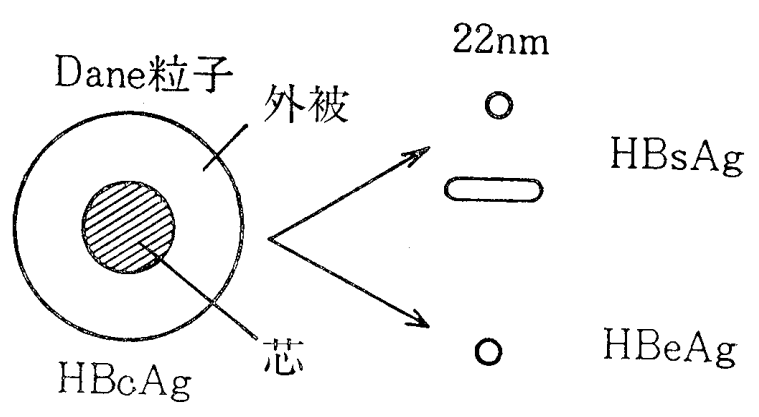

図 1 HB ウイルス関連抗原

それぞれの抗原, 抗体の出現, 消失は図 2 の ごとき経過をとり，HBsAg 陽性の期間には，



図 2 HB ウイルス関連抗原, 抗体の出現時期 $\mathrm{HBeAg}$, anti-HBe に関して次のような 3 つの 場合がある。

1) $\mathrm{HBeAg}(+)$ anti-HBe (-)

2) $\mathrm{HBeAg}(-)$ anti-HBe (-)

3) $\mathrm{HBeAg}(-)$ anti-HBe $(+)$

このらち HBeAg 陽性の時期が，病期に相当 し, 最も感染性が高く, 予防対策上注意を要す 
る時期である。しかし HBsAg 陽性でも，antiHBe 陽性になれば，感染性は非常に低いもの と考えられている. HBsAg の感染後出現時期 は，多量な HB ウイルスの感染があった場合に は，2３週間の場合もあり，感染量が少ない 場合には $3 \sim 4$ カ月ということもある. $\mathrm{HBsAg}$ 陽性の期間は，数日から数力月の幅があり，成 人の $5 \sim 10 \%$ は, 数カ月〜数年にわたってHBs Ag陽性期間が続くといわれている ${ }^{11}$. anti-HBs の出現は，HB ウイルス感染からの回復を示す ものであり，同時に，感染に対する免疫を示寸 ものである。

HB ウイルスそのものは，現在は培養が不可 能であり，動物に対する感染も，人間以外には チンパンジーしか発病しないことが，HB の研 究進歩をおくらせていたが，最近になって急速 な進歩がみられた。

\section{3. 基本的予防対策}

いずれの感染症に対しても，基本的な予防対 策を励行することが最も大切なことであり，い たずらに神経質になり過ぎることは，慎まなけ ればならない。このような観点から，次のよう な諸点を, 可能な限り注意, 励行することが望 ましい，しかしすべてを満足しなければ医療行 為が行えないというのでは，緊急の場合に患者 にとって不幸な結果を招くことにもつながり， 医療従事者として患者救命のために多少の危険 をおかさざるを得ないことも覚悟して，日頃か らそのような危険の率を少なくするよう正しい 努力を怠らないことが肝要である.

1）患者の検査および結果の表示

検査が十分に行える施設はまだ限られている が，手術前の $\mathrm{HBsAg}$ 検查，さらに $\mathrm{HBsAg}$ 陽性の場合には HBeAg，anti-HBe に関する検 査を施行し得る体制が望まれる。そしてその結 果を正しく表示し，いたずらにおてれることな く，適切な予防対策を採用することである。

2） ディスポーザブル製品の使用

使用し得るディスポーザブル製品は，その性 質からも経済的理由からも自ずと限度はあるが， 可能な範囲で採用し, 使用後焼却処理する.

\section{3）手洗いの励行}

流水による手洗いの励行は基本的予防対策上 重要なことであり，HB 患者血液等により污染 した場合には，皮膚への影響は否定できないが， $0,5 \%$ 次亜塩素酸ソーダによって洗い，さらに 石けんでよく洗うことが望ましい。

4）必要に応じた手袋の着用

作業時, 手袋着用により手指の污染を防止す ることは大切であるが，手袋を着用した安心感 から，污染した手袋であちこちに触れ，かえっ て污染を拡げるようなことは厳に慎まなければ ならない，手袋表面が污染した場合には，0.5 \%次亜塩素酸ソーダによる手袋表面の消毒を行 い，污染拡大防止に心掛けることが望ましい。

5）予防衣，マスク

必要に忘じて着用するが，污染が大きいと考 えられる際には，ディスポーザブル製品を着用 し，使用後燒却処理することが望ましい。

6）履き物

污染区域での履き物の区別，および使用後の 消毒に注意する.

7）注射針その他

注射針その他鋭利な器具による刺創，切創に 起因する感染防止には全体として細心の注意を 払うべきである。これは使用時のみでなく，使 用後なんらかの処理を行うまでの間にも，その ような危険のないよう区別して扱うべきである。 また術中，落下したり，着衣，履き物等に付着 して気付かれない縫合針からの事故防止のため に，術中使用した場合，針数の確認が望まれる.

8）輸血に際しての注意

輸血用血液の使用前 $\mathrm{HBs} A g$ 検查は確立し てきているが，一般的な注意とともに，輸血用 血液を刺入しないように留意する。

9）污染物の運搬

污染物を処理するため運搬する際に，感染を 起こさないよう注意する。他の物との区別を明 示することも必要である.

\section{4. 污染物の処理方法}

\section{4-1 ディスポーザブル製品}

污染したディスポーザブル製品は，丈夫なプ ラスチックの袋に入れ，密閉して焼却処理する. 
( 34 ) 医器学 Vol. 52, No. 3 (1982)

その際，注射針その他鋭利なものには，袋をや ぶらないような対策をほどこす．一般的な物と 区別するため，袋に明示するべきである.

\section{4-2 床，壁，手術台などの污染部位}

1） $0.5 \sim 1.0 \%$ 次亜塩素酸ソーダによる清拭ま たは液をふりかけての浸漬. 清拭後, 液をふ りかけて 5 〜0分放置する方法が最も效果的 であるたただし次亜塩素酸ソーダは金属腐蝕 性があるので，使用範囲は限定される。

2） $2 \%$ \%カリ性グルタールアルデヒドによ る清拭または液を子りかけての浸漬. 1)と同 様に清拭後液を子りかけて 5 ～10分放置して 置くのが最も效果的である

3）手術終了後の床や壁の掃除は，上記いずれ かの薬剤により，拭き掃除をする。しかし両 者とも刺激性を有するので，空気中濃度が高 くならないよう留意する。

\section{4-3 再使用する器具}

対象により，次のいすれれの処理を選択し， それを行ってから，通常の洗浄処理を行う。

1）ウォッシャーステリライザーによる処理

2) 高圧蒸気処理

$121^{\circ} \mathrm{C}, 15 \sim 20$ 分, $132^{\circ} \mathrm{C}, 10 \sim 15$ 分を一応 の目安とする。器具に付着した血液等はをとで 洗い落としにくくなる欠点はある.

3） $2 \%$ アルカリ性グルタールアルデヒド浸漬 処理

30分〜12時間浸漬する.

4) $8 \%$ ホルムアルデヒド

日本で市販されているホルマリンは，35〜 $37.5 \%$ ホルムアルデヒド溶液であるが，これを 約 $8 \%$ とし，30分〜12時間浸漬する. ホルムア ルデヒドの金属腐蝕作用に注意を要する。

5）煮沸

煮沸処理は， $98^{\circ} \mathrm{C} 30$ 分の条件で行ら ${ }^{22}$.この 条件は抵抗性の高い芽胞に詨しては無効である。

\section{5. 园療従事者の感染予防}

\section{5-1 定期検查}

年 $1 \sim 2$ 回の $\mathrm{HBs} \mathrm{Ag}$, anti-HBs 検查を行い, $\mathrm{HBsAg}$ 陽性の場合には，専門医の指示に従う。 $\mathrm{HBsAg}$ 陽性でも，感染性もほとんどなく，通 常の勤務を行える場合がある。

\section{5-2 検査結果の実例}

表 1 は，東京都B型肝炎対策専門委員会が集 計した1978年 7 月 1 日現在の都立病産院等職員 の $\mathrm{HBs} A g$, anti-HBs 陽性率 ${ }^{3)}$ であり, 図 3 は, 東大中央手術部の 5 年以上勤務者の anti-HBs 陽性率の推移である。

表 1 都立病産院等職員の HBsAg, anti-HBs 陽性率32（1978年）

\begin{tabular}{|c|c|c|c|}
\hline 職 種 & $\mathrm{n}$ & $\begin{array}{c}\text { 陽性率 } \\
\mathrm{HBs} \mathrm{Ag}\end{array}$ & $\begin{array}{l}(\%) \\
\text { anti-HBs }\end{array}$ \\
\hline 医 & 539 & 2.2 & 26.3 \\
\hline 看護婦等 & 2,792 & 1.6 & 23.9 \\
\hline 医療作業等 & 252 & 1.6 & 22.2 \\
\hline 医療技術等 & 273 & 1.5 & 18.3 \\
\hline 專 務 等 & 475 & 1.3 & 13.1 \\
\hline
\end{tabular}

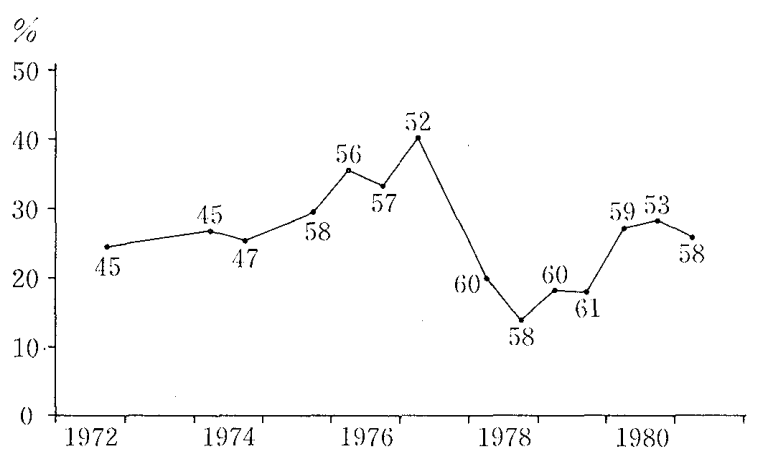

図 3 手術部職員の anti-HBs 保有率 東大中央手術部における 5 年以上勤続者62名の 集計（図中の数字は検査した人数）

また表 2 , 表 3 は国立大学病院手術部におけ る調査結果である ${ }^{4}$.

表 2 国立大学病院 4 校における手術部職員の anti-HBs 陽性率4)（1978年）

\begin{tabular}{|c|rl|}
\hline \multirow{2}{*}{ 施設 } & \multicolumn{2}{|c|}{ anti-HBs } \\
& 陽性率 & 検查法 \\
\hline B & $12 / 30(40.0 \%)$ & PHA \\
C & $4 / 36(11.1 \%)$ & ES \\
D & $11 / 40(27.5 \%)$ & PHA, RIA \\
E & $13 / 97(13.4 \%)$ & PHA \\
\hline
\end{tabular}

表 3 国立大学病院 $\mathrm{F}$ 校の HBsAg 陽性率4

\begin{tabular}{|c|c|c|c|}
\hline \multirow{2}{*}{ 年号 } & \multicolumn{3}{|c|}{ HBs Ag 陽 性 率 } \\
\hline & 手術部職員 & 病院全職員 & 手 術患者 \\
\hline 1975 & $3 / 64(4.7 \%)$ & $\begin{aligned} & 24 / 1,083 \\
&(2.2 \%)\end{aligned}$ & $\begin{array}{r}78 / 2,572 \\
(3.0 \%)\end{array}$ \\
\hline 1976 & $\begin{array}{l}3 / 66(4.6 \%) \\
3 / 63(4.8 \%)\end{array}$ & $20 / 1,495$ & $\begin{array}{l}47 / 3,471 \\
(1.4 \%)\end{array}$ \\
\hline 1977 & $\begin{array}{l}2 / 66(3.0 \%) \\
2 / 64(3.1 \%)\end{array}$ & 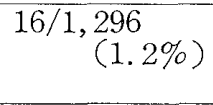 & $\begin{array}{r}37 / 3,115 \\
(1.2 \%)\end{array}$ \\
\hline
\end{tabular}




\section{5-3 事故対策}

HBsAg 陽性患者の処置中，手術中に刺創や 切創を受けたり，既存の創傷に污染を生じた場 合には，処置や手術の進行を妨げない範囲です ばやく污染創の処置を行うべきであり，たとえ 小さな刺創でも十分に処置する.

HB ウイルスに污染されたと考える創傷は， $0.5 \%$ 次亜塩素酸ソーダによる消毒後, 十分に 流水で洗浄してから，一般的処置を行う.

さらに早急に受傷者の採血を行い, $\mathrm{HBs} A g$, anti-HBs の検查を施行して，抗 HBs 人免疫グ ログリン（HBIG）の投与に備える. 同時に患 者の検査結果も再確認する. HBIG 投与の適応 は，表 4 に示すとおりであるが，最終的結論は 専門医の判断にゆだるる。

HBIG 投与は受傷後48時間以内が望ましく, $\operatorname{IgA}$ 欠損症の者に注禁忌となる.

\section{表 4 抗 HBs 人免疫グロブリン (HBIG)} 投与の適応

\begin{tabular}{|c|c|c|c|c|}
\hline $\begin{array}{l}\text { HBIG } \\
\text { 投 与 }\end{array}$ & $\begin{array}{c}\text { 患 } \\
\mathrm{HBe} \\
\mathrm{Ag}\end{array}$ & $\begin{array}{c}\text { 者 } \\
\text { anti- } \\
\mathrm{HBe}\end{array}$ & $\begin{array}{c}\text { 受 } \\
\mathrm{HBs} \\
\mathrm{Ag}\end{array}$ & $\begin{array}{l}\text { 傷 者 } \\
\text { anti- } \\
\text { HBs }\end{array}$ \\
\hline 要 & + & - & - & - \\
\hline 不 要 & $\begin{array}{l}+ \\
- \\
- \\
-\end{array}$ & $\begin{array}{l}- \\
- \\
+ \\
+\end{array}$ & $\begin{array}{l}- \\
- \\
- \\
-\end{array}$ & $\begin{array}{l}+ \\
+ \\
+ \\
-\end{array}$ \\
\hline$?$ & - & - & - & - \\
\hline 禁 忌 & $\begin{array}{l}+ \\
- \\
-\end{array}$ & $\begin{array}{l}- \\
- \\
+\end{array}$ & $\begin{array}{l}+ \\
+ \\
+\end{array}$ & $\begin{array}{l}- \\
- \\
-\end{array}$ \\
\hline
\end{tabular}

これら以外に，受傷後長時間を経過した者， $\operatorname{IgA}$ 久損症の者は禁忌となる.

表 5 に HBIG の適応とならなかった場合で, 6 カ月以上を経過し, 発症を認めなかった症例 を示す.

いずれの場合も受傷後は, 適当な間隔で追跡 検査を行う必要がある。

\section{5-4 凍結乾燥抗 HBs 人免疫グロブリンによる 受身免疫 ${ }^{5}$}

現在市販されている液状 HBIG は, その有 効期間が 1 年間と短く経済的といえない。凍結 乾燥 HBIG はその保存期間が長く, 常時保有
表 5 HBsAg 陽性患者の手術中に受傷したが HBIG 投与の適応とならなかった症例 $\mathbf{S N}$ : 縫合釬 $\mathbf{N}$ : 注射針 $\mathbf{S}:$ メス

\begin{tabular}{|c|c|c|c|c|c|}
\hline & 受 & 傷 & 者 & & 患 者 \\
\hline 症 & $\begin{array}{l}\text { 年 } \\
\text { 齢 }\end{array}$ & $\begin{array}{l}\text { 追跡期 } \\
\text { 間(月) }\end{array}$ & $\begin{array}{l}\text { anti- } \\
\text { HBs }\end{array}$ & 受傷 & $\begin{array}{l}\mathrm{HBeAg} / \\
\text { anti- } \mathrm{HBe}\end{array}$ \\
\hline 1 & 48 & $12<$ & - & $\mathrm{S} \mathrm{N}$ & $-1-$ \\
\hline 2 & 36 & $12<$ & + & $\mathrm{S} N$ & $-/-$ \\
\hline 3 & 45 & $12<$ & + & $\mathrm{N}$ & $+/-$ \\
\hline 4 & 25 & $12<$ & - & $\mathrm{SN}$ & $-\angle+$ \\
\hline 5 & 26 & 10 & - & $\mathrm{S} \mathrm{N}$ & $-/+$ \\
\hline 6 & 36 & 10 & + & $\mathrm{S} \mathrm{N}$ & $-/+$ \\
\hline 7 & 31 & 9 & + & $\mathrm{SN}$ & $-/-$ \\
\hline 8 & 29 & 9 & - & $S$ & $-/+$ \\
\hline
\end{tabular}

しておくためにはより有効な製剈である.

全国国立大学手術部連絡協議会常任幹事会安 全対策ワーキンググループで検討を行った結果 では，17例の事故症例に投与して，6 カ月以上 の経過観察で 1 例の発症例も認めていない.

その事故原因は，表 6 に示すとおりで，污染 源である HBsAg 陽性患者の $\mathrm{HBeAg}$, anti$\mathrm{HBe}$ 婊 7 のとおりである. 事故発生より HB IG 投与までの時間は表 8 に, HBIG 投与後の anti-HBs 最高值は表 9 に，投与後 6 週目にお ける抗体価は表10にそれぞれ示す。

以上より $\mathrm{HBIG}$ 投与後の PHA による抗体 価梳，やや低めの傾向ではあったが，17例すべ てに発症をみなかった。

表 6 事 故の原 因 ${ }^{5}$

\begin{tabular}{|c|c|}
\hline 事故の原因 & 症例数 \\
\hline 注 射 針 & 12 \\
縫 合 針 & 3 \\
又 & 1 \\
既存の創 & 1 \\
\hline 合計 & 17 \\
\hline
\end{tabular}

表 7 污染源である HBsAg 陽性患者の $\mathrm{HBeAg} /$ anti-HBe $^{5)}$

\begin{tabular}{|c|c|}
\hline $\mathrm{HBeAg} /$ anti-HBe & 症例数 \\
\hline$+\zeta-$ & 5 \\
$-\zeta+$ & 1 \\
$-/-$ & 7 \\
不明 & 4 \\
\hline 合計 & 17 \\
\hline
\end{tabular}


(36) 医器学 Vol. 52, No. 3 (1982)

表 8 事故発生より HBIG 投与までの時間5)

\begin{tabular}{|c|c|}
\hline 投与までの時間 & 症例数 \\
\hline$\sim 12$ & 9 \\
$\sim 24$ & 6 \\
$\sim 36$ & 0 \\
$\sim 48$ & 1 \\
$\sim 60$ & 0 \\
$\sim 72$ & 0 \\
$\sim 84$ & 1 \\
\hline 合計 & 17 \\
\hline
\end{tabular}

表 9 HBIG 投与後の anti-HBs 最高 值 (PHA) ${ }^{5)}$

\begin{tabular}{|c|c|}
\hline 抗体亚 & 症例数 \\
\hline$(-)$ & 2 \\
$2^{1}$ & 0 \\
$2^{2}$ & 10 \\
$2^{3}$ & 3 \\
不明 & 2 \\
\hline 合計 & 17 \\
\hline
\end{tabular}

表10 HBIG 投与後 6 週 目における anti HBs (PHA) ${ }^{5)}$

\begin{tabular}{|c|c|}
\hline 抗体価 & 症例数 \\
\hline$(一)$ & 5 \\
$2^{1}$ & 3 \\
$2^{2}$ & 6 \\
不明 & 3 \\
\hline 合計 & 17 \\
\hline
\end{tabular}

\section{6. おわりに}

一時は，HB に対する恐怖心が必要以上に高 くなった時期があり，HBs 抗原の抗原性不活 性化実験の結果からは，かなり厳しい滅菌条件 を示したこともあったが，その後の実験，およ び最近のチンパンジーによる感染実験の結果 ${ }^{2)}$ から，それほど抵抗性の高いウイルスではない ことが判明した。

今回ここに示した予防対策も，1つの道しる ベであり，すべての病院ですぐに実行し得るも
のではない、だからといって，患者に不利益な 結果を招くような逃避は許されるはずもなく， 特殊な $\mathrm{HB}$ 予防対策を逐次, 無理のない形で実 行に移していくとともに，基本的，一般的な予 防対策を忠実に履行することが肝要である。今 後の非 $\mathrm{A}$ 非 $\mathrm{B}$ 型肝炎の対策をも含めて, 感染症 としての肝炎を正しく認識し，基本的予防対策 を守っていくことにより，十分な感染防止効果 が得られよう。

注）本論文は昭和56年10月24日, 東京で開催された 第 53 回滅菌法研究会の講演要旨である.

(編集部)

$$
\text { 文献 }
$$

1) WHO Expert Committee on Viral Hepatitis : Advance in viral hepatitis, WHO Technical Report Series 602, 1977

2）小林寛伊他：B型肝炎ウイルスの不活性化，医 器学, $50: 524 \sim 525,1980$

3）東京都B型肝炎対策専門委員会：東京都B型肝 炎対策專門委員会答申 (改訂版), 東京都衛生 局, 1978

4）小林寛伊他：第15回全国国立大学病院手術部協 䣡会議亭録：38～43，1978

5）小林寞伊他：第18回全国国立大学病院手術部協 議会常任幹事会安全対策ワーキンググループ報 告, 手術部に抆けるB型肝炎予防対策 (II)- 凍結乾燥抗 HBs 人免疫グロブリンによる事故 時の受身免疫，1981 